\title{
Public Health Implications of Seasonality in Noxious Gases from Dumpsites in Some Niger Delta States, Nigeria
}

\author{
Glory Richard $^{1 *}$, Moses O. Nwagbara ${ }^{2}$, Vincent E. Weli ${ }^{1}$ \\ ${ }^{l}$ Department of Geography and Environmental Management, University of Port Harcourt, Choba, Port \\ Harcourt, Rivers State, Nigeria.
}

${ }^{2}$ Department of Soil Science and Meteorology, Michael Okpara University of Agriculture, Umudike, Abia State, Nigeria.

*Corresponding Author: Glory Richard, Department of Geography and Environmental Management, University of Port Harcourt, Choba, Port Harcourt, Rivers State, Nigeria.

\begin{abstract}
This study evaluated the public health implications of seasonality in air pollutants in some Niger Delta States, Nigeria. Air emission parameters $\left(\mathrm{NO}_{2}, \mathrm{SO}_{2}, \mathrm{CO}, \mathrm{NH}_{3}, \mathrm{H}_{2} \mathrm{~S}, \mathrm{VOC}\right)$ and meteorological indicators (wind speed, temperature and relative humidity) were determined at 3 distances $(3.05 \mathrm{~m}, 7.62 \mathrm{~m}$ and $15.24 \mathrm{~m}$ ) in a windward direction bimonthly for 1 calendar year covering the two predominant seasons (wet and dry) from waste dumpsites in some Niger Delta states (Delta, Bayelsa, Rivers and Abia). Portable environmental sensors were deployed for the assessment. The data collected were used to assess the health risk to those exposed following standard protocol. Data obtained were analyzed using three factorial, Spearman correlation and air quality index. The health risk assessment was carried under two background scenarios (median and geometric mean). Fifty percent of mean detected values were used for areas where emission was not detected. Results for $\mathrm{NH}_{3}, \mathrm{H}_{2} \mathrm{~S}, \mathrm{CO}, \mathrm{SO}_{2}, \mathrm{NO}_{2}$, wind speed, temperature and relative humidity ranged from $2.16-4.11 \mathrm{ppm}, 1.86-4.92 \mathrm{ppm}, 0.03-1.22 \mathrm{ppm}, 0.14-0.30,0.02-0.30 \mathrm{ppm}, 0.27-$ $2.97 \mathrm{~m} / \mathrm{s}, 27.17-33.20^{\circ} \mathrm{C}$ and $52.67-80.13 \%$ respectively. Statistically there were significant variations at $p<0.05$ for most of the parameters based on locations, distances, months/seasons and interactions. Health risk assessment revealed noxious gases and particulates were within no pollution (HRA 5 5) to hazardous pollution $(200<H R A \leq 250)$. The study showed that sensitive group of people could be mostly affected by air emissions resulting from waste dumpsite in the study area. The meteorological indicators studied (temperature, relative humidity and wind speed) revealed seasonal influence in some of the noxious gases. Hence, there is the need to exercise caution when working in these areas.
\end{abstract}

Keywords: Air quality, Environmental contaminant, Public Health, Seasons, Waste dumpsite

\section{INTRODUCTION}

Weather is a global phenomenon caused by the unequal amounts of solar energy reaching the tilting earth's surface creating pockets of warm and cold air around the earth. The resultant difference in air temperature and pressure causes warm air to rise and cold air to sink creating wind which gives rise to variation in weather conditions around the planet. Weather is never stable. It varies over time and space. The same is true for climate, which is the average weather condition over a place and over a period of time. This brings about seasons. Seasonality in climate/weather is a major factor in the socio-economic and political life style considerations of any nation. In Temperate regions, four seasons are recognizable: Summer, autumn, winter and spring while in Tropical regions like Nigeria two main seasons, dry and wet periods are predominant. The climatic features and variation in any region can be understood in terms of the various weather zones which constitute the major modules of the climate that are peculiar to the region, for instance in Nigeria harmattan (dry but humid weather) the steady rain and drizzle, the uproar line thunderstorms and the little dry season (Adejuwon, 2011). Adejuwon (2011), Ayoade (1974) reported that the various occurrence time, place, duration and intensity are determined by the location in relation to inter-tropical discontinuity. This brings about seasonality. The seasons in Nigeria is easily distinguished based on amount of rainfall, relative humidity and temperature. However, in recent times, it appears that these characteristics are gradually changing. 
The environmental implications of economic activities sustaining the Nigerian economy (oil and gas) as well as other sectors in the region are a major source of concern. The major pollutants released during flaring of hydrocarbon containing gases is noxious gases and particulates. Some of these gases include nitrogen dioxides, sulphur dioxide, volatile organic compounds like benzene, toluene, xylene and hydrogen sulfide, benzapyrene and dioxins (Donwa et al., 2015), and particulates. Other non-oil/ gas activities could further release other noxious gases such as methane under anaerobic condition and carbon monoxide during the combustion of wood biomass.

Wastes management system in Nigeria is very poor. In coastal region, municipal wastes are discharged freely into the aquatic system with little or no interference/ hindrance. In addition, sewage are also discharged into the aquatic system through the use of pier toilet system (Izah and Angaye, 2016a,b). On soil, these wastes emit offensive odors. Sometimes the receptacle is not evacuated in time leading to emission of offensive odours due to decomposition. Due to the nature of emissions resulting from wastes dump sites there is the need to frequently study it. To this effect, some studies on air quality have been carried out in waste dumpsites by Angaye and Abowei (2018), Ezekwe and Arokoyu (2017), Weli and Adekunle(2014),

Most studies on air quality in Nigeria and Niger Delta in particular focused on pollutants emanating from the oil industry. There is a paucity of information on the non-oil sectors such as waste dumpsites, food processing outfit (such as cassava processing) and wood-biomass and the correlation with climatic and meteorological indicator. For instance, gases tend to spread far and fast when the wind speed is high however, due to dilution effect the concentration may be low. During the rainy season, the spread of noxious gases may not be as rapid compared to the dry season.

Prolonged exposure to air pollutants may result in health challenges. Studies have shown that air pollution, especially particulates cause respiratory disorder (Seiyaboh and Izah, 2019; Olukoya, 2015; Ohimain and Izah, 2013). Several health challenges have been linked to air pollution associated with hydrocarbon combustion specifically due to gas flaring including cardiovascular diseases such as atherosclerosis, hypertension and ischaemic heart disease (Egwurugwu et al., 2013a; Egwurugwu and Nwafor, 2013), kidney problem (Egwurugwu et al., 2013b). Other potential health effects include bronchitis, asthma, cancers and many other gruesome ailments (Olukoya, 2015). Therefore, this study aimed at assessing the public health implications of noxious gases from waste dumpsite in some locations in the Niger Delta region of Nigeria.

\section{MATERIALS AND MeTHODS}

\subsection{Study Area}

The study area is the Niger Delta Region of Nigeria. It is located in the southern region, and has been reported to be one of the major biodiversity hotspots in the world (Izah et al., 2017a; Izah and Seiyaboh, 2018). The ecosystem is home to several breeding and nestling migratory birds, nursery ground for fisheries, and plants with pharmacological potentials. The Niger Delta has different ecological zones including barrier islands, estuarine, mangroves, freshwater swamp, lowland rainforest and creeks (Ogbe 2011; Ajao and Anurigwo, 2002). Of these, the notable once includes coastal barrier islands, mangrove swamp forests, freshwater swamps, and lowland rainforests (Donwa et al., 2015). In addition, the Niger Delta has several water bodies which harbor several biodiversity including fisheries. The predominant season in the region is 5 months of dry season (November to March of the following year) and wet season (April to October). The temperature $\left(28 \pm 8{ }^{\circ} \mathrm{C}\right)$ and relative humidity $(50-95 \%)$ is within the estimated range of the area (Izah et al., 2017b).

\subsection{Nature of the Data}

Primary data were generated during the field data gathering exercise using portable multiprobe AEROQUAL meter for Carbon monoxide (CO), Nitrogen dioxide $\left(\mathrm{NO}_{2}\right)$, Sulphur dioxide $\left(\mathrm{SO}_{2}\right)$, Hydrogen sulphide $\left(\mathrm{H}_{2} \mathrm{~S}\right)$, Ammonia $\left(\mathrm{NH}_{3}\right)$ measurement, and Portable meteorological station (Kestrel model: $4500 \mathrm{NV}$, Boothywn, USA) for measuring temperature, relative humidity and wind speed. Health risk assessment model was formulated based on the field data.

\subsection{Sampling Duration}

Noxious gases and meteorological data were obtained and analyzed bimonthly within 12 Calendar months cutting across some months in the dry season (November, January and March) as well as wet 
season (May, July and September). Sampling was conducted bimonthly and triplicate values were obtained. Samples were measured at three different distances from the proposed high emission source in a wind ward direction (i.e. 3.05, 7.62 and 15.24 meters).Four stations cutting across the four central Niger Delta states including Delta (Agbhara Otor), Bayelsa (government approved central dumpsite along Amassoma-Yenagoa road), Rivers (Elele) and Abia (Aba).

\subsection{Health Risk Assessment}

\subsubsection{Median and Geometric Means Computation}

In environmental/ecological risk assessment studies, data is commonly compared with a control. Scholars have also suggested the comparison with natural/ pre-industrial background values (Izah et al., 2017b-d). This type of data is not readily available around sites used as dumpsites. Based on this, geometric mean was used as reference which have been considered for assessing environmental risk (Bhutiani et al., 2017; Thambavani and Uma Mageswari, 2013) and median value which has been recommended by Bhutiani et al. (2017), Monakhov et al. (2015), Sarala and Sabitha (2012). Typically, the use of median which is a measure of central tendency in place of arithmetic mean shows the main trend in the index values for management purpose (Izah et al., 2017b; Sarala and Sabitha, 2012). As such the risk assessment for this study was based on two scenarios viz geometric and median means. In few instance where air pollutants were not detected, 50\% of the mean detected value was considered, a trend that have been applied by Izah et al. (2017b-d, 2018b), Bhutiani et al. (2017).

\subsubsection{Air Quality Index Calculation}

Air quality index is commonly used by government agencies to communicate to the general public the extent of environmental pollution or to make a forecast (Wikipedia, 2018). Typically an increase in air quality index is an indication that a larger populace of the locality will suffer adverse health effects. According to Angaye and Abowei (2018), Air Quality Index was developed to assess the magnitude of air pollutants in the environment. Several approaches are available for the computation of air quality index. For instances, Akinfolarin et al. (2017) used simulated emission techniques. Angaye and Abowei (2018), ACT Government (2018) reported the use of national environmental protection monitory standards. The authors further reported that this technique is a universal approach for calculating air quality index. But a developing country like Nigeria there is no permissible limits for some air pollutants that are frequently monitored. Hence in a condition where limits are not available a reference background should be developed based on the atmospheric conditions of the study area for uniformity. As such modification of the universal air quality index was made by replacing National Regulatory Limit for individual air pollutants with the background values. Hence in this study the air quality index of the respective gas was calculated as:

$$
\text { Air Quality Index }=\frac{\text { Volume of individual air emission }(\mathrm{V})}{\text { Refernece Background value (RBV) }} \times 100
$$

\subsubsection{Criteria for Comparing Air Quality Index}

Several countries of the world have applied air quality index in determining the level of air pollutants associated with human activities in different industrial setting. Some of the countries that have adopted air quality index in forecasting how clean the air is include Canada, Hong Kong, Malaysia, Mainland China, India, Mexico, Singapore, South Korea, United states, United Kingdom, Scotland among others. But information of air quality index is scantly available in Africa including Nigeria. The air quality index previously applied by Akinfolarin et al. (2017) was slightly modified. This was carried out based on the air quality index criteria of some other countries including China, India, South Korea and Singapore.

Other criteria consider were the fact that emission decreased with an increase in distances away from the emission sources. In all, the emission source at 50 feet away from the source showed less than $50 \%$ of the concentration gradient in a windward direction. The geometric mean and median mean was considered as the reference background mean at 10 feet diameter of the emission source. Based on the fact that health risk assessment is based on estimation, gases that showed a range of particular value for the two background reference values were considered as true risk. Table 1 presents the air quality index finally used in this study. 
Public Health Implications of Seasonality in Noxious Gases from Dumpsites in Some Niger Delta States, Nigeria

Table1. Criteria for the assessment of Air Quality Index in this study

\begin{tabular}{|c|c|c|}
\hline Air Quality Index & Levels of Health Concern & Implication on human health \\
\hline HRA $\leq 50$ & No pollution & $\begin{array}{c}\text { No impact on human health over a prolong } \\
\text { period of time }\end{array}$ \\
\hline $50<\mathrm{HRA} \leq 100$ & Slightly polluted & $\begin{array}{c}\text { Impact could predispose individuals expose some } \\
\text { health risk especially among immunocompromised } \\
\text { patients over a prolong period of time }\end{array}$ \\
\hline $100<\mathrm{HRA} \leq 150$ & Moderately polluted & $\begin{array}{c}\text { Impact could predispose individuals expose some } \\
\text { health risk especially among immunocompromised } \\
\text { patients (including infants, children and elderly) over } \\
\text { a short period of time }\end{array}$ \\
\hline $150<\mathrm{HRA} \leq 200$ & Significantly/Densely polluted & $\begin{array}{c}\text { Impact could elicit respiratory response (asthma, } \\
\text { lungs etc) especially in infants, children, elderly ( }>70 \\
\text { years) and other immune-compromized individuals }\end{array}$ \\
\hline HRA $>250$ & Hazardous & $\begin{array}{c}\text { High response could including itching of the eye, } \\
\text { respiratory condition among individuals (including } \\
\text { infants, children, adolescent, adult and elderly) } \\
\text { exposed to the pollutant over a period }>6 \text { hours } \\
\text { depending on the type of pollutant }\end{array}$ \\
\hline Very Hazardous $\leq 250$ & $\begin{array}{c}\text { High response could including itching of the } \\
\text { eye, respiratory condition among individuals } \\
\text { including infants, children, adolescent, adult } \\
\text { and elderly) exposed to the pollutant over a } \\
\text { period < } 6 \text { hours depending on the type of } \\
\text { pollutant }\end{array}$ \\
\hline
\end{tabular}

\subsubsection{Techniques of Data Analysis}

SPSS software version 20 was used to carry out the statistical analysis. Analysis of field data on the ambient air quality across the four test stations of gaseous emissions such as Carbon monoxide (CO), Nitrogen dioxide $\left(\mathrm{NO}_{2}\right)$, Sulphur dioxide $\left(\mathrm{SO}_{2}\right)$, ammonia $\left(\mathrm{NH}_{3}\right)$ and Hydrogen sulphide $\left(\mathrm{H}_{2} \mathrm{~S}\right)$. A three-way analysis of variance was carried out at $\alpha=0.05$. Where significant difference occurred Duncan multiple range test statistics was used to compare the means. Spearman rho correlation matrix was used to show significant relationship between the various parameters at $\alpha=0.05$ and 0.01 .

\section{RESULTS AND DISCUSSION}

\subsection{Concentration of the Noxious Gases}

The bimonthly, spatial emissions and distances of air quality results from waste dumpsite in some Niger Delta states are presented in Table 1,2 and 3 respectively. The p-value of the statistical analysis of months, locations, and distances and their various interactions is presented in Table 4.

\subsection{Ammonia}

The concentration of ammonia in the various months of study ranged from $1.34-2.37$ ppm. There was significant variations at $\mathrm{p}<0.05$ in the various months of study (Table 1). The spatial-temporal distribution of ammonia in the study area ranged from $1.52 \mathrm{ppm}-2.47 \mathrm{ppm}$, being significantly different at $\mathrm{p}<0.05$ among the various locations apart from locations $\mathrm{B}$ and $\mathrm{C}$ that showed no significant difference at $\mathrm{p}>0.05$ based on pair wise comparison (Table 2). Based on distances ammonia ranged from $0.88-3.02 \mathrm{ppm}$. Ammonia concentration showed significant decline at $\mathrm{p}<0.05$ as distance increased (Table 3). On interaction of months and location, months and distance, distance and location, and months, distance and locations, there was significant variation at $\mathrm{p}<0.001$ (Table 4).

Ammonia concentration at dump sites for the various months studied showed significant variation across distances due to dilution effects from air movement and characteristics of the wastes. Soil organic matter containing wastes could also contribute to seasonal variation in ammonia concentration among the various months studied. Generally, ammonia concentration gradient was high during the dry season for waste dump sites. The higher ammonia concentration suggests seasonal influence (Angaye et al., 2018). The concentration of ammonia in all four objects of study declined as distance away from the emission source increased. This trend have been reported in smallholders oil palm processing in Rivers state by Ohimain et al. (2013), by semi-mechanized processors in Bayelsa state by Ohimain and Izah (2013). Apart from waste dumpsites, the value of ammonia across the areas of 
Public Health Implications of Seasonality in Noxious Gases from Dumpsites in Some Niger Delta States, Nigeria

study is in the range of $<0.01-0.667 \mathrm{ppm}$ at 3.05 meter (10 feet distance), $<0.01-0.267 \mathrm{ppm}$ at 7.62 meter ( 25 feet distance) and $<0.01 \mathrm{ppm}$ at 15.24 meter ( 50 feet distance) in a windward direction from smallholder oil palm processing (Ohimain et al., 2013) and value of $0.01-0.2 \mathrm{ppm}$ during combined activities of boiling and digestion from semi-mechanized palm oil mill (Ohimain and Izah, 2013).The ammonia values from waste dumpsite is close to the value of $0.3-3 \mathrm{ppm}$ from Eliozo/Eligbolo and Obigbo In Port Harcourt, River state (Ezekwe and Arokoyu, 2017), but far higher than the value of $0-0.300 \mathrm{mg} / \mathrm{m}^{3}$ from dump site in Rumuolumeni, Port Harcourt, River state (Weli and Adekunle, 2014). The variation could be due to the physical nature of the dumpsite.

Table1. Bimonthly distribution of noxious gases from waste dumpsite in the Niger Delta region of Nigeria

\begin{tabular}{|c|c|c|c|c|c|c|}
\hline \multirow{2}{*}{ Parameters } & \multicolumn{6}{|c|}{ Months } \\
\cline { 2 - 7 } & Nov & Jan & Mar & May & July & Sept \\
\hline $\mathrm{NH}_{3}, \mathrm{ppm}$ & $2.11 \mathrm{c}$ & $2.00 \mathrm{c}$ & $2.37 \mathrm{~d}$ & $1.61 \mathrm{~b}$ & $1.34 \mathrm{a}$ & $2.04 \mathrm{c}$ \\
\hline $\mathrm{H}_{2} \mathrm{~S}, \mathrm{ppm}$ & $2.44 \mathrm{c}$ & $2.41 \mathrm{c}$ & $2.08 \mathrm{~b}$ & $1.73 \mathrm{a}$ & $1.78 \mathrm{a}$ & $1.70 \mathrm{a}$ \\
\hline $\mathrm{CO}, \mathrm{ppm}$ & $0.53 \mathrm{c}$ & $0.52 \mathrm{c}$ & $0.11 \mathrm{~b}$ & $0.01 \mathrm{a}$ & $0.01 \mathrm{a}$ & $0.01 \mathrm{a}$ \\
\hline $\mathrm{SO}_{2}, \mathrm{ppm}$ & $0.19 \mathrm{c}$ & $0.09 \mathrm{~b}$ & $0.10 \mathrm{~b}$ & $0.07 \mathrm{ab}$ & $0.05 \mathrm{a}$ & $0.09 \mathrm{ab}$ \\
\hline $\mathrm{NO}_{2}, \mathrm{ppm}$ & $0.14 \mathrm{~d}$ & $0.06 \mathrm{bc}$ & $0.04 \mathrm{~b}$ & $0.08 \mathrm{c}$ & $0.05 \mathrm{~b}$ & $0.02 \mathrm{a}$ \\
\hline
\end{tabular}

Means (36) with Different letters across the row indicate significant difference at $\mathrm{p}<0.05$ according to Duncan multiple range test statistics

Table2. Spatial distribution of noxious gases from waste dumpsite in the Niger Delta region of Nigeria

\begin{tabular}{|c|c|c|c|c|}
\hline \multirow{2}{*}{ Parameters } & \multicolumn{4}{|c|}{ Locations } \\
\cline { 2 - 5 } & Bayelsa & Rivers & Delta & Abia \\
\hline $\mathrm{NH}_{3}, \mathrm{ppm}$ & $2.47 \mathrm{c}$ & $1.52 \mathrm{a}$ & $1.59 \mathrm{a}$ & $2.07 \mathrm{~b}$ \\
\hline $\mathrm{H}_{2} \mathrm{~S}, \mathrm{ppm}$ & $2.95 \mathrm{~d}$ & $1.55 \mathrm{~b}$ & $1.21 \mathrm{a}$ & $2.40 \mathrm{c}$ \\
\hline $\mathrm{CO}, \mathrm{ppm}$ & $0.27 \mathrm{~b}$ & $0.13 \mathrm{a}$ & $0.26 \mathrm{~b}$ & $0.12 \mathrm{a}$ \\
\hline $\mathrm{SO}_{2}, \mathrm{ppm}$ & $0.11 \mathrm{a}$ & $0.08 \mathrm{a}$ & $0.10 \mathrm{a}$ & $0.10 \mathrm{a}$ \\
\hline $\mathrm{NO}_{2}, \mathrm{ppm}$ & $0.10 \mathrm{c}$ & $0.08 \mathrm{bc}$ & $0.01 \mathrm{a}$ & $0.07 \mathrm{~b}$ \\
\hline
\end{tabular}

Means (54) with Different letters across the row indicate significant difference at $\mathrm{p}<0.05$ according to Duncan multiple range test statistics

Table3. Distance distribution of noxious gases from waste dumpsite in the Niger Delta region of Nigeria

\begin{tabular}{|c|c|c|c|}
\hline \multirow{2}{*}{ Parameters } & \multicolumn{3}{|c|}{ Distance, meter } \\
\cline { 2 - 4 } & 3.05 & 7.62 & 15.24 \\
\hline $\mathrm{NH}_{3}, \mathrm{ppm}$ & $3.02 \mathrm{c}$ & $1.83 \mathrm{~b}$ & $0.88 \mathrm{a}$ \\
\hline $\mathrm{H}_{2} \mathrm{~S}, \mathrm{ppm}$ & $3.33 \mathrm{c}$ & $2.03 \mathrm{~b}$ & $0.72 \mathrm{a}$ \\
\hline $\mathrm{CO}, \mathrm{ppm}$ & $0.44 \mathrm{c}$ & $0.12 \mathrm{~b}$ & $0.02 \mathrm{a}$ \\
\hline $\mathrm{SO}_{2}, \mathrm{ppm}$ & $0.23 \mathrm{c}$ & $0.05 \mathrm{~b}$ & $0.01 \mathrm{a}$ \\
\hline $\mathrm{NO}_{2}, \mathrm{ppm}$ & $0.14 \mathrm{c}$ & $0.05 \mathrm{~b}$ & $0.01 \mathrm{a}$ \\
\hline
\end{tabular}

Means (72) with Different letters across the row indicate significant difference at $\mathrm{p}<0.05$ according to Duncan multiple range test statistics

Table4. P-values of noxious gases from waste dumpsite in the Niger Delta region of Nigeria

\begin{tabular}{|c|c|c|c|c|c|c|c|}
\hline $\begin{array}{c}\text { Paramet } \\
\text { ers }\end{array}$ & $\begin{array}{c}\text { Month } \\
\mathrm{s}\end{array}$ & $\begin{array}{c}\text { Locatio } \\
\mathrm{ns}\end{array}$ & $\begin{array}{c}\text { Distanc } \\
\text { es }\end{array}$ & $\begin{array}{c}\text { Interaction of } \\
\text { months and location }\end{array}$ & $\begin{array}{c}\text { Interaction } \\
\text { of months } \\
\text { and } \\
\text { distance }\end{array}$ & $\begin{array}{c}\text { Interaction } \\
\text { of distance } \\
\text { and location }\end{array}$ & $\begin{array}{c}\text { of months, } \\
\text { locations } \\
\text { and } \\
\text { distance }\end{array}$ \\
\hline $\begin{array}{c}\mathrm{NH}_{3}, \\
\mathrm{ppm}\end{array}$ & 0.000 & 0.000 & 0.000 & 0.000 & 0.000 & 0.001 & 0.000 \\
\hline $\begin{array}{c}\mathrm{H}_{2} \mathrm{~S}, \\
\mathrm{ppm}\end{array}$ & 0.000 & 0.000 & 0.000 & 0.000 & 0.000 & 0.000 & 0.001 \\
\hline $\begin{array}{c}\mathrm{CO}, \\
\mathrm{ppm}\end{array}$ & 0.000 & 0.000 & 0.000 & 0.000 & 0.000 & 0.000 & 0.000 \\
\hline $\begin{array}{c}\mathrm{SO} \\
\mathrm{ppm}\end{array}$ & 0.000 & 0.273 & 0.000 & 0.000 & 0.006 & 0.625 & 0.826 \\
\hline $\begin{array}{c}\mathrm{NO}_{2}, \mathrm{pp} \\
\mathrm{m}\end{array}$ & 0.000 & 0.000 & 0.000 & 0.000 & 0.000 & 0.000 & 0.000 \\
\hline
\end{tabular}




\subsection{Hydrogen Sulphide}

Hydrogen sulphide concentration in the various months of study ranged from $1.70-2.44 \mathrm{ppm}$. There was significant difference at $p<0.05$ among the various months of study (Table 1). The spatialtemporal distribution of hydrogen sulphide ranged from $1.21 \mathrm{ppm}-2.95 \mathrm{ppm}$. There was significant difference at $\mathrm{p}<0.05$ among the various locations of study (Table 2). Based on distances hydrogen sulphide ranged from $0.72-3.33 \mathrm{ppm}$. Hydrogen sulphide concentration showed a significant decline at $p<0.05$ further away from the emission source (Table 3 ). Like ammonia, hydrogen sulphide showed significant $(\mathrm{p}<0.00)$ interactions between months and location, months and distance, distance and locations, and months, distances and locations (Table 4).

Again the significant difference in the hydrogen sulphide could be due to air movement (based on distances), characteristics of the wastes (locations). Hydrogen sulphide concentrations were significantly lower during the different months of study in the wet season (May, July and September). The interactions showed that varying months, distances, locations have effects on hydrogen sulphide concentrations. The trend reported in waste dumpsite is slightly different from the trend reported by Anagye et al. (2018) with hydrogen sulphide (0.42 - 6.95 ppm during the dry season and $0.07-7.44$ ppm during the wet season). Rim-Rukeh (2014) reported hydrogen sulphide concentration in the range of 3.4-7.7 ppm from dumpsite being combusted. The hydrogen sulphide concentration from waste dumpsite is higher than the value of $0.06-0.08 \mathrm{ppm}$ from Eliozo/Eligbolo and Obigbo in Port Harcourt, River state (Ezekwe and Arokoyu, 2017), but far higher than the value of $0.084-0.404$ $\mathrm{mg} / \mathrm{m}^{3}$ from dump site in Rumuolumeni, Port Harcourt, River state (Weli and Adekunle, 2014). The variation could be due to the physical nature of the dumpsite as well as seasonal influence.

\subsection{Carbon Monoxide}

The carbon monoxide concentration among the various months of study ranged from $<0.01-0.53$ $\mathrm{ppm}$. There was significant variations at $\mathrm{p}<0.05$ among the various months (Table 1 ). The spatialtemporal distribution of carbon monoxide ranged from $0.12-0.21 \mathrm{ppm}$. There was significant difference at $\mathrm{p}<0.05$ among the locations. But pairwise comparison showed no significant difference at $\mathrm{p}>0.05$ between location $\mathrm{A}$ and $\mathrm{C}$, and $\mathrm{B}$ and $\mathrm{D}$ (Table 2). The concentration of carbon monoxide based on distance ranged from $0.02-0.44 \mathrm{ppm}$. Carbon monoxide concentration showed significant decline at $\mathrm{p}<0.05$ as distances increases (further emission source) (Table 3 ). On interaction of months and location, months and distance, distance and location, and months, distance and locations, carbon monoxide showed that there was significant variation at $\mathrm{p}<0.001$ (Table 4).

The significant variations at $\mathrm{p}<0.05$ among distances showed the effect of air movement, locations showed the effect of varying amount of the wastes in the dumpsite, and the effects during the seasons showed the effect of combustion in the various locations during the dry season as against wet season. The carbon monoxide concentration were lower than the Daily average of hourly values and $10 \mathrm{ppm}$ $\left(11.4 \mu \mathrm{g} / \mathrm{m}^{3}\right)$ and 8 -hourly average value of $20 \mathrm{ppm}\left(22.8 \mu \mathrm{g} / \mathrm{m}^{3}\right)$ as reported by FEPA (1992) among the various activities under consideration in this study.

The carbon-monoxide emission was higher during the dry season; this is understandable due to the effect of combustion process during the dry season which is now becoming a normal trend dumpsite in the Niger Delta (Angaye et al., 2018; Izah et al., 2017a). The carbon-monoxide concentration from waste dumpsite is higher during the dry season a trend that has been reported by Angaye et al. (2018). The values reported in this study were close to the value of $0.18-1.23 \mathrm{ppm}$ in dry season and 0.00 $0.54 \mathrm{ppm}$ in wet season from dumpsites in Yenagoa metropolis, Bayelsa state. During combustion processes of biomass, waste and gasoline carbon monoxide is emitted.

\subsection{Sulphur Dioxide}

Sulphur dioxide concentration among the various months of study ranged from $0.05-0.19 \mathrm{ppm}$. Basically, there was significant variations at $\mathrm{p}<0.05$ among the various months (Table 1). The spatialtemporal distribution of Sulphur dioxide ranged from $0.08-0.11 \mathrm{ppm}$. No significant difference at p $>0.05$ among the locations (Table 2). The Sulphur dioxide concentration based on distance ranged from $0.01-0.23 \mathrm{ppm}$. Like other noxious gases (carbon monoxide, ammonia, hydrogen sulphide and nitrogen dioxide), the concentration of Sulphur dioxide showed significant decline at $\mathrm{p}<0.05$ as distances increased (Table 3). On interaction of months and locations, months and distances significant difference at $\mathrm{p}<0.05$ exist for sulphur dioxide, but the distances and location, and months, distances and locations no significant variation at $p>0.05$ exits on their interactions (Table 4 ). 
Public Health Implications of Seasonality in Noxious Gases from Dumpsites in Some Niger Delta States, Nigeria

The concentration of Sulphur dioxide was higher than the daily average of $0.01 \mathrm{ppm}\left(26 \mu \mathrm{g} / \mathrm{m}^{3}\right)$ and lower than the hourly values of $0.1 \mathrm{ppm}\left(260 \mu \mathrm{g} / \mathrm{m}^{3}\right)$ for Nigerian ambient air quality except for waste dumpsite that has higher sulphur dioxide value. The values reported in the dumpsite in this study is comparable to the value of $0.01-0.81 \mathrm{ppm}$ in both wet and dry season from waste dump site in Yenagoa metropolis (Angaye et al., 2018), $0.22-0.23 \mathrm{ppm}$ in a landfill in port Harcourt (Ezekwe and Arokoyu, 2017), and $0.026-1.677 \mathrm{mg} / \mathrm{m}^{3}$ around landfill site in Rumuolumeni, Port Harcourt metropolis (Weli and Adekunle, 2014).

\subsection{Nitrogen Dioxide}

The concentration of nitrogen dioxide in the various months of study ranged from $0.02-0.14 \mathrm{ppm}$. The result shows significant difference at $\mathrm{p}<0.05$ among the various months (Table 1 ). The spatialtemporal distribution showed that nitrogen dioxide concentration ranged from $0.01-0.10 \mathrm{ppm}$. Significant difference at $\mathrm{p}<0.05$ exist among the locations (Table 2). The nitrogen dioxide concentration based on distances ranged from $0.01-0.14 \mathrm{ppm}$. The nitrogen dioxide concentration showed significant decrease at $\mathrm{p}<0.05$ as the distances away from the emission source increases (Table 3). On interaction of months and location, months and distance, distance and location, and months, distance and locations, nitrogen dioxide showed significant variations at $\mathrm{p}<0.001$ (Table 4).

The significant variation that occurred suggests that seasons, distances and locations have the tendency to interfere with the concentration of nitrogen dioxide in the study area. Season affects the concentration of nitrogen dioxide. Nitrogen dioxide was higher than Nigeria ambient air quality value of $0.04 \mathrm{ppm}-0.06 \mathrm{ppm}\left(75.0 \mu \mathrm{g} / \mathrm{m}^{3}-113 \mu \mathrm{g} / \mathrm{m}^{3}\right)$ for daily average (FEPA, 1991). The nitrogen dioxide value in this study were close to the range of $0.01-0.82 \mathrm{ppm}$ for dry season and $0.01-0.33 \mathrm{ppm}$ in wet season from waste dumpsite in Yenagoa metropolis (Angaye et al., 2018), $0.1-0.39 \mathrm{mg} / \mathrm{m}^{3}$ in landfill in Rumuolumeni, Port Harcourt, River state (Weli and Adekunle, 2014), $0.05-0.12 \mathrm{ppm}$ in dumpsite Abakiliki of Ebonyi state (Njoku, 2015). Furthermore, the values reported in this study is also close values of $0.133-1.167 \mathrm{ppm}$ reported during palm oil processing by smallholders in Rivers state (Ohimain et al., 2013), <0.01 - $0.2 \mathrm{ppm}$ in semi-mechanized palm oil mill in Bayelsa state (Ohimain and Izah, 2013).

\subsection{Health Risk Assessment of the Noxious Gases}

The air quality index of noxious gases from waste dumpsite in some locations in the Niger Delta is presented in Table 5. Health risk assessment based on ammonia concentration ranged from slight pollution $(50<\mathrm{HRA} \leq 100)$ to moderate pollution $(100<\mathrm{HRA} \leq 150)$ across both seasons and backgrounds (geometric means and median mean) under consideration (Table 5). Locations B (Rivers state) and C (Delta state) revealed slight pollution $(50<\mathrm{HRA} \leq 100)$, while locations A (Bayelsa state) and $\mathrm{D}$ (Abia state) showed moderate pollution $(100<\mathrm{HRA} \leq 150)$ for waste dumpsites. The health risk ranged from no pollution (HRA $\leq 50)$ to hazardous $(200<\mathrm{HRA} \leq 250)$. Dumpsite values show moderate pollution for Location A (Bayelsa) and D (Abia), and slight pollution for location B (Rivers) and C (Delta). The health risk index of carbon monoxide revealed slight pollution $(50<\mathrm{HRA} \leq 100)$ to significant pollution $(150<\mathrm{HRA} \leq 200)$. The values higher in wet season in some instances across the various months. This could be due to moisture content of the biomass and materials being combusted (Ohimain et al., 2013). Carbon dioxide health hazard tend to affect mostly sensitive group of people in both wet and dry season. Furthermore, higher health risk has also been observed in location A (Bayelsa). Basically, carbon dioxide is emitted from incomplete combustion of carbonaceous materials or fossil fuels (gas, oil), coal and wood (Seiyaboh and Izah, 2019).

Table5. Air quality index of associated with waste dumpsite in some locations in the Niger Delta

\begin{tabular}{|c|c|c|c|c|c|c|c|c|c|c|c|}
\hline $\begin{array}{c}\text { Locatio } \\
\text { ns }\end{array}$ & \multirow{2}{*}{$\begin{array}{c}\text { Mean } \\
\text { considerati } \\
\text { on }\end{array}$} & \multicolumn{2}{|c|}{ Ammonia } & \multicolumn{2}{|c|}{$\begin{array}{l}\text { Hydrogen } \\
\text { sulphide }\end{array}$} & \multicolumn{2}{|c|}{$\begin{array}{c}\text { Carbon } \\
\text { monoxide }\end{array}$} & \multicolumn{2}{|c|}{$\begin{array}{l}\text { Sulphur } \\
\text { dioxide }\end{array}$} & \multicolumn{2}{|c|}{$\begin{array}{c}\text { Nitrogen } \\
\text { dioxide }\end{array}$} \\
\hline & & Dry & Wet & Dry & Wet & Dry & Wet & Dry & Wet & Dry & Wet \\
\hline \multirow[t]{2}{*}{$\mathrm{A}$} & Geometric & $\begin{array}{c}122.6 \\
9\end{array}$ & $\begin{array}{c}128.6 \\
3\end{array}$ & $\begin{array}{c}137.0 \\
5\end{array}$ & $\begin{array}{c}127.4 \\
5\end{array}$ & $\begin{array}{c}148.7 \\
8\end{array}$ & $\begin{array}{c}150.0 \\
0\end{array}$ & $\begin{array}{c}103.5 \\
7\end{array}$ & $\begin{array}{c}122.2 \\
2\end{array}$ & $\begin{array}{c}250.0 \\
0\end{array}$ & $\begin{array}{c}100.0 \\
0\end{array}$ \\
\hline & Median & $\begin{array}{c}122.3 \\
2\end{array}$ & $\begin{array}{c}132.1 \\
6\end{array}$ & $\begin{array}{c}145.5 \\
6\end{array}$ & $\begin{array}{c}127.4 \\
5\end{array}$ & $\begin{array}{c}145.2 \\
4\end{array}$ & $\begin{array}{c}200.0 \\
0\end{array}$ & $\begin{array}{c}100.0 \\
0\end{array}$ & $\begin{array}{c}115.7 \\
9\end{array}$ & $\begin{array}{c}150.0 \\
0\end{array}$ & 92.31 \\
\hline \multirow[t]{2}{*}{ B } & Geometric & 81.49 & 82.44 & 88.58 & 82.69 & 70.73 & 75.00 & $\begin{array}{c}107.1 \\
4\end{array}$ & 77.78 & 17.50 & $\begin{array}{c}133.3 \\
3\end{array}$ \\
\hline & Median & 81.25 & 84.71 & 94.08 & 76.47 & 69.05 & $\begin{array}{c}100.0 \\
0\end{array}$ & $\begin{array}{c}103.4 \\
5\end{array}$ & 73.68 & $\begin{array}{c}105.0 \\
0\end{array}$ & $\begin{array}{c}123.0 \\
8\end{array}$ \\
\hline
\end{tabular}


Public Health Implications of Seasonality in Noxious Gases from Dumpsites in Some Niger Delta States, Nigeria

\begin{tabular}{|c|c|c|c|c|c|c|c|c|c|c|c|}
\hline C & Geometric & 91.94 & 89.31 & 74.37 & 65.72 & 130.0 & 75.00 & 100.0 & 100.8 & 16.67 & 58.33 \\
& & & & & & 4 & 9 & & \\
& Median & 91.67 & 91.76 & 78.99 & 60.78 & 127.3 & 100.0 & 96.55 & 84.21 & 90.00 & 107.6 \\
& & & & & & 8 & 0 & & & 9 \\
\hline \multirow{2}{*}{$\mathrm{D}$} & Geometric & 108.3 & 105.3 & 110.8 & 133.5 & 74.39 & 75.00 & 92.86 & 116.6 & 150.0 & 116.6 \\
& & 6 & 4 & 6 & 7 & & & & 7 & 0 & 7 \\
\cline { 2 - 11 } & Median & 108.0 & 108.2 & 117.7 & 123.5 & 72.62 & 100.0 & 89.66 & 110.5 & 90.00 & 107.6 \\
& & 4 & 4 & 5 & 3 & & 0 & & 3 & & 9 \\
\hline
\end{tabular}

HRA $\leq 50$ (No pollution); $50<\mathrm{HRA} \leq 100$ (Slightly polluted); $100<\mathrm{HRA} \leq 150$ (Moderately polluted); $150<$ HRA $\leq 200$ (Significantly/Densely polluted); 200<HRA $\leq 250$ (Hazardous); HRA $>250$ (Very Hazardous)

Health risk assessment of Sulphur dioxide values ranged from no pollution $(\mathrm{HRA} \leq 50)$ to moderate pollution $(100<\mathrm{HRA} \leq 150)$. The health risk will mostly affect sensitive group of people and in few instances it could also be detrimental to all group of individuals. The health risk did not showed a particular trend this is because of the variation among the various locations. The quantity and moisture contents and physical composition of the materials being combusted also affect the emission pattern (especially during the dry season). Typically, sulphur dioxide which has sharp smell, and it has the tendency to react with other compounds (Seiyaboh and Izah, 2019). The air quality index of Nitrogen dioxide ranged from no pollution (HRA $\leq 50)$ to hazardous pollution $(200<\mathrm{HRA} \leq 250)$. The health risk index were within no pollution to dense pollution except for dry season value of location $\mathrm{A}$ (Bayelsa state) under geometric mean consideration that showed hazardous pollution. Typically in the environment decomposition of wastes is the major source of nitrogen in the air (Angaye et al., 2018; Weli and Adekunle, 2014; Njoku, 2015).

\subsection{Relationship Between the Noxious Gases and Meteorological Indicators}

The correlations matrix of the various parameters under study for waste dumpsite is presented in Table 6. Ammonia showed positive significant relationship with hydrogen sulphide $(r=0.799)$, carbon monoxide $(r=0.417)$, sulphur dioxide $(r=0.739)$, nitrogen dioxide $(r=0.509)$ at $p<0.01$. Hydrogen sulphide showed positive significant correlation with carbon monoxide $(\mathrm{r}=0.467)$, sulphur dioxide $(r=0.653)$, nitrogen dioxide $(r=0.580)$ at $\mathrm{p}<0.01$. Carbon monoxide showed positive significant relationship with sulphur dioxide $(r=0.456)$, nitrogen dioxide $(r=0.302)$ at $p<0.01$, wind speed $(r=0.161)$ at $\mathrm{p}<0.05$, and negatively correlate with relative humidity $(r=-0.340)$. Sulphur dioxide showed positive significant relationship with nitrogen dioxide $(r=0.485)$, volatile organic compounds $(\mathrm{r}=0.609)$ at $\mathrm{p}<0.01$.

There was high significant relationship between the noxious gases (nitrogen dioxide, Sulphur dioxide, carbon monoxide, hydrogen sulphide, ammonia suggesting that the emissions are from similar source (Izah et al., 2017b). Furthermore in some instances meteorological factors had effect on emissions. Studies have shown that significant correlations is an indication that the emissions are from common source and mutually dependent, while negative significant relationship is an indication of mutually independent variables (Izah et al., 2017b; Jiang et al., 2014; Rodriguez et al., 2008).

Table6. Spearman's rho of the air quality and meteorology of selected dumpsites in the Niger Delta region of Nigeria

\begin{tabular}{|c|c|c|c|c|c|c|c|c|}
\hline Parameters & $\mathrm{NH}_{4}$ & $\mathrm{H}_{2} \mathrm{~S}$ & $\mathrm{CO}$ & $\mathrm{SO}_{2}$ & $\mathrm{NO}_{2}$ & W/S & TEMP & RH \\
\hline $\mathrm{NH}_{4}$ & 1.000 & & & & & & & \\
\hline $\mathrm{H}_{2} \mathrm{~S}$ & $0.799^{* * *}$ & 1.000 & & & & & & \\
\hline $\mathrm{CO}$ & $0.417^{* * *}$ & $0.467^{* *}$ & 1.000 & & & & & \\
\hline $\mathrm{SO}_{2}$ & $0.739^{* *}$ & $0.653^{* *}$ & $0.456^{* *}$ & 1.000 & & & & \\
\hline $\mathrm{NO}_{2}$ & $0.509^{* *}$ & $0.580^{* *}$ & $0.302^{* *}$ & $0.485^{* *}$ & 1.000 & & & \\
\hline $\mathrm{VOC}$ & $0.675^{* *}$ & $0.651^{* *}$ & $0.358^{* *}$ & $0.609^{* *}$ & $0.433^{* *}$ & & & \\
\hline $\mathrm{W} / \mathrm{S}$ & 0.095 & 0.117 & $0.161^{* *}$ & 0.103 & 0.051 & 1.000 & & \\
\hline $\mathrm{TEMP}$ & 0.070 & 0.114 & $0.249^{* *}$ & 0.081 & -0.104 & 0.083 & 1.000 & \\
\hline $\mathrm{RH}$ & -0.112 & -0.132 & $-0.340^{* *}$ & -0.128 & 0.064 & -0.058 & $-0.914^{* *}$ & 1.00 \\
\hline
\end{tabular}

**. Correlation is significant at the 0.01 level (2-tailed).

*. Correlation is significant at the 0.05 level (2-tailed).

$N=218$ (months $=6$, Location $=4$, distance $=3$, replicate $=3$ )

International Journal of Research Studies in Biosciences (IJRSB) 
Public Health Implications of Seasonality in Noxious Gases from Dumpsites in Some Niger Delta States, Nigeria

\subsection{Impacts of the Meteorological Parameters on Noxious Gases Based on Seasons}

The metrological characteristics of the study area based on bimonthly, locations and distances for all the activities under study is presented in Table 7, 8, 9, respectively. While the p-values for all locations, distances and bimonthly and their interaction is presented in Table 10. The wind speed at the dumpsite in the various months of study ranged from $0.91-1.27 \mathrm{~m} / \mathrm{s}$, being significantly different at $\mathrm{p}<0.05$ in the various months studied (Table 7). The spatial-temporal distribution of wind speed around dumpsites ranged from $0.89-1.36 \mathrm{~m} / \mathrm{s}$ (Table 8). The wind speed level showed significant difference at $p>0.05$ except at $15.24 \mathrm{~m}$ distance (Table 9). Wind speed showed significant interactions at $\mathrm{p}<0.05$ with distances, months and locations (Table 10).

The atmospheric temperature at the dumpsite ranged from $29.76-32.13{ }^{\circ} \mathrm{C}$, being significantly different at $\mathrm{p}<0.05$ among the various months studied (Table 7). The spatial-temporal distribution of temperature at the dumpsites ranged from $30.96-31.63{ }^{\circ} \mathrm{C}$ (Table 8). The temperature based on distance ranged from $31.23-31.31{ }^{\circ} \mathrm{C}$, which do not show significant difference at $\mathrm{p}>0.05$ except at $7.62 \mathrm{~m}$ distance (Table 9). Temperature exhibited significant interactions at $\mathrm{p}<0.05$ on distances, months and locations (Table 10). The significant differences that occur indicates the effects of temperature on emission of noxious gases with regards to distances, locations and months around waste dumpsite in core Niger Delta states of Nigeria.

The relative humidity at the dumpsite in the various months of study from core Niger Delta states ranged from $58.39-70.13 \%$, being significantly different at $\mathrm{p}<0.05$ among the various months studied (Table 7). The spatial-temporal distribution of relative humidity at the dumpsites ranged from $60.83-65.07 \%$ (Table 8). The relative humidity percentage based on distance ranged from $62.69-$ $63.36 \%$. Basically there was significant difference at $\mathrm{p}<0.05$ among the various distances (Table 9). Like, temperature, relative humidity showed significant interactions at $\mathrm{p}<0.05$ on distances, months and locations (Table 10). The significant differences that occurred indicate the effects of relative humidity on emission of noxious gases with regard to distances, locations and months around waste dumpsite in core Niger Delta states of Nigeria.

Table7. Bimonthly distribution of meteorology of waste dumpsite in the Niger Delta region of Nigeria

\begin{tabular}{|c|c|c|c|c|c|c|}
\hline \multirow{2}{*}{ Parameters } & \multicolumn{6}{|c|}{ Months } \\
\cline { 2 - 7 } & Nov & Jan & Mar & May & July & Sept \\
\hline Wind speed, $\mathrm{m} / \mathrm{s}$ & $1.27 \mathrm{~b}$ & $1.05 \mathrm{ab}$ & $1.11 \mathrm{ab}$ & $1.08 \mathrm{ab}$ & $0.91 \mathrm{a}$ & $1.23 \mathrm{~b}$ \\
\hline Temperature, ${ }^{\circ} \mathrm{C}$ & $31.58 \mathrm{c}$ & $32.13 \mathrm{e}$ & $31.83 \mathrm{~d}$ & $29.76 \mathrm{a}$ & $31.11 \mathrm{~b}$ & $31.17 \mathrm{~b}$ \\
\hline Relative humidity, $\%$ & $61.14 \mathrm{c}$ & $58.39 \mathrm{a}$ & $60.42 \mathrm{~b}$ & $70.13 \mathrm{f}$ & $64.61 \mathrm{e}$ & $63.61 \mathrm{~d}$ \\
\hline
\end{tabular}

Means (36) with Different letters across the row indicate significant difference at $p<0.05$ according to Duncan multiple range test statistics

Table8. Spatial distribution of meteorology of waste dumpsite in the Niger Delta region of Nigeria

\begin{tabular}{|c|c|c|c|c|}
\hline \multirow{2}{*}{ Parameters } & \multicolumn{4}{|c|}{ Locations } \\
\cline { 2 - 4 } & Bayelsa & Rivers & Delta & Abia \\
\hline Wind speed, $\mathrm{m} / \mathrm{s}$ & $0.89 \mathrm{a}$ & $1.09 \mathrm{~b}$ & $1.10 \mathrm{~b}$ & $1.36 \mathrm{c}$ \\
\hline Temperature, $^{\circ} \mathrm{C}$ & $31.28 \mathrm{c}$ & $30.96 \mathrm{a}$ & $31.63 \mathrm{~d}$ & $31.17 \mathrm{~b}$ \\
\hline Relative humidity, $\%$ & $62.96 \mathrm{~b}$ & $65.07 \mathrm{c}$ & $60.83 \mathrm{a}$ & $63.33 \mathrm{~b}$ \\
\hline
\end{tabular}

Means (54) with Different superscript letters across the row indicate significant difference at $p<0.05$ according to Duncan multiple range test statistics

Table9. Distance distribution of meteorology in waste dumpsite in the Niger Delta region of Nigeria

\begin{tabular}{|c|c|c|c|}
\hline \multirow{2}{*}{ Parameters } & \multicolumn{3}{|c|}{ Distance, meter } \\
\cline { 2 - 4 } & 3.05 & 7.62 & 15.24 \\
\hline Wind speed, $\mathrm{m} / \mathrm{s}$ & $1.19 \mathrm{~b}$ & $1.16 \mathrm{~b}$ & $0.98 \mathrm{a}$ \\
\hline Temperature, $^{\circ} \mathrm{C}$ & $31.25 \mathrm{a}$ & $31.31 \mathrm{~b}$ & $31.23 \mathrm{a}$ \\
\hline Relative humidity, $\%^{\circ}$ & $63.10 \mathrm{ab}$ & $62.69 \mathrm{a}$ & $63.36 \mathrm{~b}$ \\
\hline
\end{tabular}

Means (72) with Different superscript letters across the row indicate significant difference at $\mathrm{p}<0.05$ according to Duncan multiple range test statistics 
Public Health Implications of Seasonality in Noxious Gases from Dumpsites in Some Niger Delta States, Nigeria

Table10. $P$-values of meteorology in the waste dumpsite in the Niger Delta region of Nigeria

\begin{tabular}{|c|c|c|c|c|c|c|c|}
\hline Parameters & $\begin{array}{c}\text { Mont } \\
\text { hs }\end{array}$ & $\begin{array}{c}\text { Locatio } \\
\text { ns }\end{array}$ & $\begin{array}{c}\text { Distanc } \\
\text { es }\end{array}$ & $\begin{array}{c}\text { Interaction of months and } \\
\text { location }\end{array}$ & $\begin{array}{c}\text { Interacti } \\
\text { on of } \\
\text { months } \\
\text { and } \\
\text { distance }\end{array}$ & $\begin{array}{c}\text { Interacti } \\
\text { on of } \\
\text { distance } \\
\text { and } \\
\text { location }\end{array}$ & $\begin{array}{c}\text { Interacti } \\
\text { on of } \\
\text { months, } \\
\text { location } \\
\text { s and } \\
\text { distance }\end{array}$ \\
\hline Wind speed, $\mathrm{m} / \mathrm{s}$ & 0.009 & 0.009 & 0.006 & 0.000 & 0.000 & 0.019 & 0.007 \\
\hline Temperature, ${ }^{\circ} \mathrm{C}$ & 0.000 & 0.000 & 0.009 & 0.000 & 0.001 & 0.000 & 0.000 \\
\hline $\begin{array}{c}\text { Relative } \\
\text { humidity, } \%\end{array}$ & 0.000 & 0.000 & 0.015 & 0.000 & 0.014 & 0.012 & 0.006 \\
\hline
\end{tabular}

Based on Table 7-9 values, temperature was lower during the wet season compared to dry season. Similarly the relative humidity was higher in dry season than wet season. This trend has been widely reported in literature (Uba, 2015; Angaye et al., 2018). Meteorological values in this study have some similarly with the work of Angaye et al. (2018) that reported temperature in the range 31.33- 33.7 for dry season and 27.91- 28.48 ${ }^{\circ} \mathrm{C}$ for wet season, relative humidity of $57.24-61.84$ in dry season and $82.93-86.58 \%$ in wet season and wind speed of $1.22-3.49 \mathrm{~m} / \mathrm{s}$ in dry season and $0.73-5.25 \mathrm{~m} / \mathrm{s}$ in wet season. The wind speed of this study is within the limit of $0.51-1.8 \mathrm{~m} / \mathrm{s}$ previously described as calm wind speed (Pillay et al., 2011). Ohimain and Izah (2013) reported $30.0-31.5{ }^{\mathrm{O}} \mathrm{C}$ (temperature), $71.8-79.6 \%$ (relative humidity) and $0.7-0.9 \mathrm{mls}$ (wind speed) in wind-ward direction from semimechanized palm oil processing in Bayelsa state. Ohimain et al. (2013) also reported atmospheric temperature during boiling in the range of $27.93-35.80^{\circ} \mathrm{C}$ at 3.05 meter (10feet) distance, $27.43-$ $35.40{ }^{\circ} \mathrm{C}$ at 7.62 meter $\left(25\right.$ feet) distance and $27.53-34.03{ }^{\circ} \mathrm{C}$ at 15.24 meter (50 feet) distance in wind ward direction and $27.93-35.63^{\circ} \mathrm{C}$ at 3.05 meter (10feet) distance, $27.27-35.50{ }^{\circ} \mathrm{C}$ at 7.62 meter (25 feet) distance, and $27.33-35.93{ }^{\circ} \mathrm{C}$ at 15.24 meter (50 feet) distance in the lee ward direction; wind speed of $0.100-1.567 \mathrm{~m} / \mathrm{s}$ during boiling activity and $0.133-0.933 \mathrm{~m} / \mathrm{s}$ during digestion; and relative humidity of $62.40-86.60 \%$ during boiling and $60.79-86.43 \%$ during digestion activity in smallholder palm oil processing mill in Nigeria during the wet season. Izah et al. (2015) reported temperature $\left(24-35^{\circ} \mathrm{C}\right)$, relative humidity $(69.2-86.9 \%)$ and wind speed $(0.3-$ $1.3 \mathrm{~m} / \mathrm{s}$ ) in August, 2014 in Yenagoa metropolis, Bayelsa state, Nigeria in wet season. In most of the activities studied, temperature decreased at increasing distances from source (Ohimain et al., 2013; Ohimain and Izah, 2013). The wind speed recorded in this study indicates light air based on Beaufort scale classification. The wind speed and direction affected the concentration of air quality parameters significantly (Ohimain et al., 2013). The high values obtained in some locations and distance from each of the activity may be due to reduced cloud cover and the influence of moisture laden tropical maritime air mass (Ohimain et al., 2013; Ohimain and Izah, 2013). Ohimain et al. (2013), Miguel et al. (2004), Litvak et al. (2000) reported that enhance deposition of particles could influence meteorological indicators (Miguel et al., 2004; Litvak et al., 2000). As such relative humidity may have influenced emissions at varying distances. Weli and Adekunle (2014) also reported that temperature and relative humidity could affect the concentration of noxious gases such as nitrogen dioxide, ammonia and hydrogen sulphide. Authors have widely reported that metrological indicators affect the fate of pollutant gases in the environment (Uba, 2015; Weli and Adekunle, 2014; Cossu and Reiter 1996).

\subsection{Potential Health Implications of the Air Pollutant}

The overall seasonal values (dry and wet seasons) and the various background values (median mean and geometric mean) used in this study for waste dumpsite are presented in Table 11.

In the waste dumpsite, the concentration of ammonia for dry and wet season was in the range of 2.73 $-4.11 \mathrm{ppm}$ and $2.16-3.37 \mathrm{ppm}$, respectively for ammonia. Based on the air quality index, there pollution especially among the sensitive group of people. Typically, ammonia is a noxious gas that could lead to irritation of the skin, eye, nose, throat and respiratory tract at high concentration (Seiyaboh and Izah, 2019). According to Department of Health (2005), ammonia in the respiratory tract could cause a lot of discomfort to the respiratory system. The health risk in this study revealed that sensitive individuals could be affected via dermal, ingestion and inhalation processes at the recorded concentrations of ammonia in the activities studied. The severity of ammonia exposure depends on the duration as well as the concentration. 
Public Health Implications of Seasonality in Noxious Gases from Dumpsites in Some Niger Delta States, Nigeria

Table11. Overall of seasonal influence for each of the gases in the waste dumpsite in the Niger Delta region of Nigeria

\begin{tabular}{|c|c|c|c|c|c|c|c|c|c|c|c|c|}
\hline \multirow{2}{*}{$\begin{array}{c}\text { Parameter } \\
\text { s }\end{array}$} & $\mathrm{A}$ & $\mathrm{B}$ & $\mathrm{C}$ & $\mathrm{D}$ & $\begin{array}{c}\text { Geo } \\
\text { mean }\end{array}$ & $\begin{array}{c}\text { Media } \\
\mathrm{n} \\
\text { mean }\end{array}$ & $\mathrm{A}$ & $\mathrm{B}$ & $\mathrm{C}$ & $\mathrm{D}$ & $\begin{array}{c}\text { Geo } \\
\text { mean }\end{array}$ & $\begin{array}{c}\text { Media } \\
\mathrm{n} \\
\text { mean }\end{array}$ \\
\hline $\mathrm{NH}_{3}, \mathrm{ppm}$ & $\begin{array}{c}4.1 \\
1\end{array}$ & $\begin{array}{c}2.7 \\
3\end{array}$ & $\begin{array}{c}3.0 \\
8\end{array}$ & $\begin{array}{c}3.6 \\
3\end{array}$ & 3.35 & 3.36 & $\begin{array}{c}3.3 \\
7\end{array}$ & $\begin{array}{c}2.1 \\
6\end{array}$ & $\begin{array}{c}2.3 \\
4\end{array}$ & $\begin{array}{c}2.7 \\
6\end{array}$ & 2.62 & 2.55 \\
\hline $\mathrm{H}_{2} \mathrm{~S}, \mathrm{ppm}$ & $\begin{array}{c}4.9 \\
2\end{array}$ & $\begin{array}{c}3.1 \\
8\end{array}$ & $\begin{array}{c}2.6 \\
7\end{array}$ & $\begin{array}{c}3.9 \\
8\end{array}$ & 3.59 & 3.58 & 3.9 & $\begin{array}{c}2.3 \\
4\end{array}$ & $\begin{array}{c}1.8 \\
6\end{array}$ & $\begin{array}{c}3.7 \\
8\end{array}$ & 2.83 & 3.06 \\
\hline $\mathrm{CO}, \mathrm{ppm}$ & $\begin{array}{c}1.2 \\
2\end{array}$ & $\begin{array}{c}0.5 \\
8\end{array}$ & $\begin{array}{c}1.0 \\
7\end{array}$ & $\begin{array}{c}0.6 \\
1\end{array}$ & 0.82 & 0.84 & $\begin{array}{c}0.0 \\
6\end{array}$ & $\begin{array}{c}0.0 \\
3\end{array}$ & $\begin{array}{c}0.0 \\
3\end{array}$ & $\begin{array}{c}0.0 \\
3\end{array}$ & 0.04 & 0.03 \\
\hline $\mathrm{SO}_{2}, \mathrm{ppm}$ & $\begin{array}{c}0.2 \\
9\end{array}$ & 0.3 & $\begin{array}{c}0.2 \\
8\end{array}$ & $\begin{array}{c}0.2 \\
6\end{array}$ & 0.28 & 0.29 & $\begin{array}{c}0.2 \\
2\end{array}$ & $\begin{array}{c}0.1 \\
4\end{array}$ & $\begin{array}{c}0.1 \\
6\end{array}$ & $\begin{array}{c}0.2 \\
1\end{array}$ & 0.18 & 0.19 \\
\hline $\mathrm{NO}_{2}, \mathrm{ppm}$ & 0.3 & $\begin{array}{c}0.2 \\
1\end{array}$ & $\begin{array}{c}0.0 \\
2\end{array}$ & $\begin{array}{c}0.1 \\
8\end{array}$ & 0.12 & 0.12 & $\begin{array}{c}0.1 \\
2\end{array}$ & $\begin{array}{c}0.1 \\
6\end{array}$ & $\begin{array}{c}0.0 \\
7\end{array}$ & $\begin{array}{c}0.1 \\
4\end{array}$ & 0.12 & 0.13 \\
\hline
\end{tabular}

The overall concentration of hydrogen sulphide for dry and wet season ranged from $2.67-4.92 \mathrm{ppm}$ and $1.86-3.90 \mathrm{ppm}$, respectively, being higher during the dry. From the air quality index, there is potential pollution especially to the sensitize group across both season. Typically, hydrogen sulphide is a noxious gas that is highly flammable and has rotten egg smell. On exposure it could irritate the respiratory tracts and cause pulmonary edema (Seiyaboh and Izah, 2019; ATSDR, 2014). Hence based on the findings of this study sensitive people are mostly at risk of hydrogen sulphide toxicity.

The concentration of carbon monoxide in dry and wet season was in the range of $0.58-1.22 \mathrm{ppm}$ and $0.03-0.06 \mathrm{ppm}$, respectively. From the health risk assessment, sensitive group of people could be affected mostly especially during the dry season. Generally, carbon monoxide can interact with the haemoglobin and hinder blood supply to some vital organs such as the heart and brain. When the concentration of carbon monoxide exceeds the tolerable level in the body it could lead to the formation of carboxyhaemoglobin (Seiyaboh and Izah, 2019; Ohimain et al., 2013; Abelsohn et al., 2002). Based on the health risk index all categories of people are at risk of carbon monoxide toxicity due to exposure but could be more detrimental to sensitive group.

Sulphur dioxide concentration for dry and wet season ranged from $0.26-0.30$ ppm and $0.14-0.22$ ppm respectively. From the health risk assessment sensitive people are prone to suffer from adverse effect of Sulphur dioxide as emissions. Sulphur dioxide has the capacity to irritate the nose and throat, cause cough, breathlessness (Department of the Environment and Heritage, 2005). But the health risk values in this study suggests that sensitive group of people may be at risk of Sulphur dioxide pollution.

The level of nitrogen dioxide in dry and wet season were in the range of $0.02-0.30 \mathrm{ppm}$ and $0.07-$ $0.14 \mathrm{ppm}$ respectively. Again, the sensitive group tends to suffer high effect of nitrogen dioxide. Basically, high concentration of nitrogen dioxide is associated to increased risk of respiratory and cardiovascular diseases which could cause liver and kidney diseases (Seiyaboh and Izah, 2019; Ohimain et al., 2013; Umesi et al., 2009). The tendency of nitrogen dioxide to cause health effect depends on the concentration and exposure period.

\section{CONCLUSION}

In the waste dumpsite, the values generally showed significant variation between the various locations, distances, months and their interactions. All the noxious gases (ammonia, hydrogen sulphide, carbon monoxide, Sulphur dioxide, nitrogen dioxide). These parameters also showed Significant difference at $\mathrm{p}<0.05$ also exit for locations except for Sulphur dioxide. Majority of the parameters showed positive significant interactions between months and distances, months and locations, locations and distances, and months, locations and distances. The meteorological indicators (wind speed, temperature, relative humidity) showed a significant variations at $\mathrm{p}<0.05$ for the various distances. Temperature correlates with carbon monoxide positively. Wind speed positively correlate with carbon monoxide and volatile organic compounds. Suggesting that meteorology positively influenced carbon monoxide concentrations. On the overall all Sulphur dioxide and nitrogen dioxide often exceed the FEPA limit in some locations and activities. However, the values for carbon 
monoxide within the FEPA limit for all the locations across the two predominant season of study. Based on air quality index, the sensitive group of individuals could be affected on exposure which will depend on the exposure period. Generally, in noxious gases, there was a decline in air emissions are distance away from the emission source increased. There were spatial and months variance among the air pollutants, while changes in climatic conditions slightly affected the meteorological indicators. Based on the health risk assessment observed in this study, it is necessary to enhance proper waste management in the study areas through proper evacuation and recycling using suitable technologies.

\section{REFERENCES}

[1] Abelsohn, A., Stieb, D., Sanborn, M.D., and Weir, E. (2002). Identifying and managing adverse environmental health effects: 2. Outdoor air pollution. CMAJ, 166(9),1161-1167

[2] ACT Government (2018). What is an Air Quality Index?. Retrieved October 2018 from http://health.act.gov.au/public-information/public-health/act-air-quality-monitoring/air-quality-index-aqi.

[3] Adejuwon, J.O. (2011). Rainfall seasonality in the Niger Delta Belt, Nigeria. Journal of Geography and Regional Planning, 5(2), 51-60.

[4] Agency for Toxic Substances and Disease Registry (ATSDR) (2014). Toxic Substances Portal - Hydrogen Sulfide Carbonyl Sulfide. https://www.atsdr.cdc.gov/mmg/mmg.asp?id=385\&tid=67. Accessed March 5th 2018 .

[5] Ajao, E.A., and Anurigwo, S. (2002). Land-based sources of pollution in the Niger Delta, Nigeria. Ambio, 31(5), $442-445$.

[6] Akinfolarin, O. M., Boisa, N., and Obunwo, C. C. (2017). Assessment of Particulate Matter-Based Air Quality Index in Port Harcourt, Nigeria. J Environ Anal Chem., 4, 224. doi:10.4172/2380-2391.1000224.

[7] Angaye, T. C. N., Daokoru-Olukole, C., Abowei, J. F. N. (2018). Environmental Impacts of Municipal Solid Wastes in Yenagoa Metropolis, Bayelsa State, Nigeria. Biotechnol. Res., 4(1), 17-23.

[8] Angaye, T. C., and Abowei, J. F. N. (2018). Evaluation of suspended particulate matter (SPM) around municipal solid waste dumpsites in Yenagoa metropolis, Nigeria. MOJ Toxicology, 4(2), 54-57.

[9] Ayoade, J.O. (1974). A statistical analysis of rainfall over Nigeria. J. Trop. Geog., 39: 11-23.

[10] Bhutiani, R., Kulkarni, D. B., Khanna, D. R., and Gautam, A. (2017). Geochemical distribution and environmental risk assessment of heavy metals in groundwater of an industrial area and its surroundings, Haridwar, India. Energy, Ecology and Environment, 2(2), 155-167.

[11] Cossu, R., and Reiter, M. (1996). Landfill gas condensate production and disposal, In T.H. Christensen, R. Stegmann, R. Cossu, (editors) Landfilling of Waste. Published by Taylor and Francis Books Ltd., pp. 485.

[12] Department of Health (2005). The Facts About Ammonia. https://www.health.ny.gov/environmental/ emergency/chemical_terrorism/ammonia_tech.htm. Accessed March 5th 2018

[13] Department of the Environment and Heritage (2005). Sulfur dioxide (SO2). http://www.environment.g ov.au/ protection/publi cations/factsheet-sulfur-dioxide-so2. Accessed 5 march 2018.

[14] Donwa, P.A., Mgbame, C.O., and Utomwen, O.A. (2015). Gas flaring in the oil and gas sector in Nigeria. International Journal of Commerce and Management Research, 1(1), 28-39

[15] Egwurugwu, J.N., and Nwafor, A. (2013). Prolonged Exposure to Oil and Gas Flares Ups the Risks for Hypertension. American Journal of Health Research 1(3), 65-72.

[16] Egwurugwu, J.N., Nwafor A, Chinko BC, Oluronfemi OJ, Iwuji SC, Nwankpa, P. (2013a). Effects of prolonged exposure to gas flares on the lipid profile of humans in the Niger Delta region, Nigeria. American Journal of Research Communication, 1(5): 115-145.

[17] Egwurugwu, J.N., Nwafor, A., Oluronfemi, O.J., Iwuji, S.C. and Alagwu, E.A. (2013b). Impact of Prolonged Exposure to Oil and Gas Flares on Human Renal Functions. International Research Journal of Medical Sciences, 1(11): 9-16

[18] Ezekwe, I.C., and Arokoyu, S.B. (2017). Landfill Emissions and their Urban Planning and Environmental Health Implications in Port Harcourt, South-South Nigeria. Desenvolv. MeioAmbiente, 42,224-241.

[19] Federal Environmental Protection Agency (FEPA) (1991). National interim Guidelines and Standards for Industrial effluents, Gaseous emissions and Hazardous wastes. Environmental Pollution Control Handbook. Lagos, Nigeria.

[20] Izah S.C. and Seiyaboh E.I. (2018). Changes in the protected areas of Bayelsa state, Nigeria. International Journal of Molecular Evolution and Biodiversity, 8(1), 1-11.

[21] Izah S.C., Bassey S.E., and Ohimain E.I. (2018). Ecological risk assessment of heavy metals in cassava mill effluents contaminated soil in a rural community in the Niger Delta Region of Nigeria. Molecular Soil Biology, 9(1), 1-11 
Public Health Implications of Seasonality in Noxious Gases from Dumpsites in Some Niger Delta States, Nigeria

[22] Izah S.C., Angaye C.N., Aigberua A.O., and Nduka J.O. (2017a). Uncontrolled bush burning in the Niger Delta region of Nigeria: potential causes and impacts on biodiversity. International Journal of Molecular Ecology and Conservation, 7(1): 1-15.

[23] Izah S.C., Bassey S.E., and Ohimain E.I. (2017b). Assessment of heavy metal in cassava mill effluent contaminated soil in a rural community in the Niger Delta region of Nigeria. EC Pharmacology and Toxicology, 4(5): 186-201.

[24] Izah S.C., Bassey S.E., and Ohimain E.I. (2017c). Geo-accumulation index, enrichment factor and quantification of contamination of heavy metals in soil receiving cassava mill effluents in a rural community in the Niger Delta region of Nigeria. Molecular Soil Biology, 8(2): 7-20.

[25] Izah S.C., Bassey S.E., and Ohimain E.I. (2017d). Assessment of pollution load indices of heavy metals in cassava mill effluents contaminated soil: a case study of small-scale cassava processing mills in a rural community of the Niger Delta region of Nigeria. Bioscience Methods, 8(1), 1-17.

[26] Izah, S.C., and Angaye, T.C.N. (2016a). Ecology of Human Schistosomiasis intermediate host and Plant Molluscicides used for control: A review. Sky Journal of Biochemistry Research. 5(6), 075- 082

[27] Izah, S.C., and Angaye, T.C.N. (2016b). Heavy metal concentration in fishes from surface water in Nigeria: Potential sources of pollutants and mitigation measures. Sky Journal of Biochemistry Research, 5(4), 31-47.

[28] Izah, S.C., Angaye, T.C.N. and Ohimain, E.I. (2015). Climate change: some meteorological indicators and perception of farmers in Yenagoa metropolis, Bayelsa state, Nigeria. International Journal of Geology, Agriculture and Environmental Sciences, 3(1), 56- 60.

[29] Jiang, X., Lu, W. X., Zhao, H. Q., Yang, Q. C., and Yang, Z. P. (2014). Potential ecological risk assessment and prediction of soil heavy-metal pollution around coal gangue dump. Natural Hazards and Earth System Science, 14, 1599-1610.

[30] Litvak, A., Gadgil, A.J., and Fisk, W.J. (2000). Hygroscopic fine mode particle deposition on electronic circuits and resulting degradation of circuit performance: an experimental study. Indoor Air, 10, 47-56.

[31] Miguel, A.F., Reis, A.H., and Aydin, M. (2004). Aerosol particle deposition and distribution in bifurcating ventilation ducts. J. Hazard Mater 116, 249-55.

[32] Monakhov, S., Esina, O., Monakhova, G., and Tatarnikov, V. (2015). Environmental quality assessment: geoenvironmental indices. In: Environmental indicators. Armon, R. H., and Hanninen, O. (Eds.). Dordrecht: Springer, doi: 10.1007/978-94-017-9499-2. ISBN 973-94-017-9498-5.

[33] Njoku, C. (2014). Effect of Waste Dumpsites on Water and Air Qualities in Abakaliki, Southestern Nigeria. International Journal of Plant and Soil Science, 4(5), 455 - 460.

[34] Ogbe, M.G. (2011). Managing the environmental challenges of the oil and gas industry in the Niger Delta. Nigeria Journal of Life Science, 1 (1), 1 - 17.

[35] Ogwu, F.A., Peters, A.A., Aliyu, H.B., and Abubakar, N. (2015). An Investigative Approach on the Effect of Air Pollution on Climate Change and Human Health in the Niger Delta Region of Nigeria. International Journal of Scientific Research and Innovative Technology, 2(5), 37- 49.

[36] Ohimain, E.I., and Izah, S.C. (2013). Gaseous emissions from a semi-mechanized oil palm processing mill in Bayelsa state, Nigeria. Continental Journal of Water, Air and Soil Pollution, 4 (1), 15 - 25.

[37] Ohimain, E.I., Izah, S.C., and Abah, S.O. (2013). Air quality impacts of smallholder oil palm processing in Nigeria. Journal of Environmental Protection, 4, 83-98.

[38] Olukoya, O.A.P. (2015). Negative Effects of Gas Flaring On Buildings and Public Health in Oil Producing Communities: The Ogbia Community, Bayelsa State Case. International Journal of Environmental Monitoring and Protection, 2(5), 52-61.

[39] Pillay, B., Zunckel, M., Shongwe, B., and Oosthuizen, R. (2011). Air Quality Impact Assessment for the Proposed Upgrade of the Kwadukuza Landfill Site. A report for Metamorphosis Environmental Consulting, uMoya-NILU Consulting (Pty) Ltd, Report No. uMN002-09. 121p.

[40] Rodríguez, J. A., Nanos, N., Grau, J. M., Gil, L., and López-Arias, M. (2008). Multiscale analysis of heavy metal contents in Spanish agricultural topsoils. Chemosphere, 70, 1085-1096.

[41] Sarala, T.D., and Sabitha, M.A. (2012). Calculating Integrated Pollution Indices for Heavy Metals in Ecological Geochemistry Assessment Near Sugar Mill. Journal of Research in Biology, 2(5), 489-498.

[42] Seiyaboh, E.I., and Izah, S.C. (2019). Impacts of soil pollution on air quality under Nigerian setting. Journal of Soil and Water Science, 3(1), 45-53.

[43] Thambavani, S.D., and Uma Mageswari, U.T.S.R. (2013). Metal pollution assessment in ground water. Bulletin of Environmental Pharmacology Life Science, 2(12), 122-129.

[44] Uba, S. (2015). Environmental Impact Assessment of Dumpsites in Zaria Metropolis, Kaduna State, Nigeria. M.Sc Thesis, Ahmadu bello University, Zaria Nigeria. 
Public Health Implications of Seasonality in Noxious Gases from Dumpsites in Some Niger Delta States, Nigeria

[45] Umesi, N.O., Ideria, J.T., and Abah, S. (2009). Background concentration of NO2 prior to Construction and Operation of a Gas-Fired Gas Plant in the Niger Delta Region of Nigeria. Environment \& Ecology, 27 (2): 592-602.

[46] Weli, V.E., and Adekunle, O. (2014). Air Quality in the Vicinity of a Landfill Site in Rumuolumeni, Port Harcourt, Nigeria. Journal of Environment and Earth Science, 4(10): 1 - 9.

[47] Wikipedia (2018). Air quality index. https://en.wikipedia.org/ wiki/Air_quality_index\#Public _Availability_of_the_AQI

Citation: Glory Richard, et.al. "Public Health Implications of Seasonality in Noxious Gases from Dumpsites in Some Niger Delta States, Nigeria" International Journal of Research Studies In Biosciences (Ijrsb), Vol. 7, no. 5, pp. 9-22, 2019. http://Dx.Doi.org/10.20431/2349-0365.0705002

Copyright: (C) 2019 Authors. This is an open-access article distributed under the terms of the Creative Commons Attribution License, which permits unrestricted use, distribution, and reproduction in any medium, provided the original author and source are credited. 